\title{
Form and structure in engineering
}

\author{
by \\ R. H. Evans, C.B.E., D.Sc., D.es.Sc., Ph.D., M.I.C.E., M.I.Mech.E. \\ and
}

W. Houghton-Evans, A.R.I.B.A., A.M.T.P.I.

Mr A. J. Harris (Partner, A. J. \& J. D. Harris) said the Paper had four features. The first was the title which referred to a matter of great moment. The second was the Authors' presentation, which he applauded. The third was their summary which was an impressive statement in its own right. The fourth was the Paper itself which seemed to have little to do with the other three features.

66. Referring to the last point, he was obliged to say that he found this vague, pseudo-architectural, would-be aesthetic philosophizing profoundly antipathetic. There were people who were stimulated by it into a self-generated ecstatic mood which looked from the outside much like that of artistic creation; it was in fact no such thing.

67. The stumbling block was beauty. It was pointless to talk about aesthetics, and he was glad to see the word inserted in the Paper between inverted commas; aesthetics did not exist, but beauty did; like the elephant, it was difficult to define, but recognizable when seen. His own motto was Eric Gill's-'Look after truth and goodness and beauty looks after herself'; this seemed a very good principle for engineers and even-dare he suggest it ?-for architects.

68. Architects and engineers were united in their concern with the production of articles of utility. The distinction between fine art and useful art was mentioned in the Paper. He would call attention to a different definition, a slightly more antique one. The Greek philosophers graded the arts according to the degree in which there was employment of material. To play the flute was one sort of artistic creation; to carve a two-ton block of marble was a very different one. First, it was necessary to buy and handle the marble; secondly, the sculptor had to maintain in his mind the image of what he was trying to do during a long period of hard work. From that point of view, and feeling that that definition went much deeper than might at first appear, engineers and architects were singularly impure artists, since they were dealing with large quantities of matter, labour and somebody else's money, possibly running into millions of pounds. The expressive, artistic element in such an undertaking must of necessity be dilute.

69. The first requirement, indeed, was to produce objects of utility. Here the modern movement came in. The Authors had given an admirable summary of the various attitudes to form and structure, but Mr Harris would suggest that, at the moment, the key point was different from that which they mentioned; the key was function. It was 45 years since Le Corbusier first stated that a house was a machine for living in. This had given rise to an engineering style, whilst the actual mechanics had been little changed. They should now be attempting to make buildings which were really machines for living in.

* Proc. Instn civ. Engrs, vol. 27, February 1964, pp. 263-290 
70. At the moment, structure, with which so much of the Paper was concerned, represented between $20 \%$ and $25 \%$ of the cost of a building. A very large proportion of the rest went in the various services which provided the artificial environment and climate which they sought. This should now be the source of architectural inspiration; it had much to offer. He protested vigorously against structures such as Nervi's conference hall for U.N.E.S.C.O. being put forward as examples of the embodiment of structural principles. It had a 128-ft span roof of an extreme and wholly unnecessary complication, enormously heavy despite its great structural depth. The complication satisfied no apparent need; its justification would impress no-one who had ever seen a bending moment diagram.

71. Were Greek and Gothic architecture the outward expressions of structure? He suggested not. Banister Fletcher had pointed out in considerable detail the precise representation in classical Greek masonry of a hundred-and-one details of timber construction. The typical Greek temple was, in fact, a timber temple built in stone, which was as if one were to build a reinforced concrete beam with rivet heads cast on the side and artificial cleats where it joined the column. Gothic architecture looked more like stone engineering until one realized that those exquisite vaulted roofs were supplemented by a very complicated timber roof itself covered with lead. It was difficult to see what structural lesson could be learned from this.

72. Coming to the last part of the Paper, the suggestion that engineers should be taught something about design was to be applauded. It was their attitudes to design which, at the moment, divided engineers from architects. The engineer left college convinced that design was a matter of deciding how many bars should be in the beam, whereas the only design decision of any significance was that to have a beam.

73. Design was an art, and an art could be learned only in practice; it was exceedingly difficult to teach. He was convinced that it was more of a contagion and came, as it were, from the laying on of hands, but it was good to see that engineering students were at least made aware of the fact that there was such a thing as design. How this should best be done he did not know, but his own nostrum was that pupils should be taught at least a course of appreciation of engineering structures. Why should there be an arch? Why a simply-supported beam? Why not a continuous beam? He gave hearty applause to the Authors for their proposal in this respect; it would mean a most important step forward in the education of engineers.

Mr R. J. Mainstone (Principal Scientific Officer, Building Research Station) also applauded the aims of the present approach to the teaching of structural design at Leeds and wished the Authors well in their endeavours. Some of the students' work shown on the screen had been most encouraging. It was all the more regrettable, therefore, that so little had been said in the Paper about recent teaching experience. Without knowing more about this in a number of ways, it was hardly possible to comment usefully on it.

75. The Paper was largely a courageous statement of the Authors' basic philosophy. Their humanist credo was plainly declared. Beyond that, though, it was not easy to grasp how they themselves considered that the 'enthusiastic and sympathetic desire to understand and to satisfy those for whose use we design' was to be realized in the practical choices of structure and form.

76. The relationship between these was, of course, of vital interest here. It had two aspects - a structural one and an aesthetic one. For 'those for whose use we design', the latter perhaps weighed most heavily, provided that the structure stood and did not cost too much. But, for the engineer designer, the former had to come first. In ensuring that the structure would stand, he was, and always had been, interested in its geometric form primarily as a determinant of its structural action.

77. It was the Authors' belief that, 'if we are to understand how form and structure are related, some study of the architecture of past ages' was 'an appropriate 


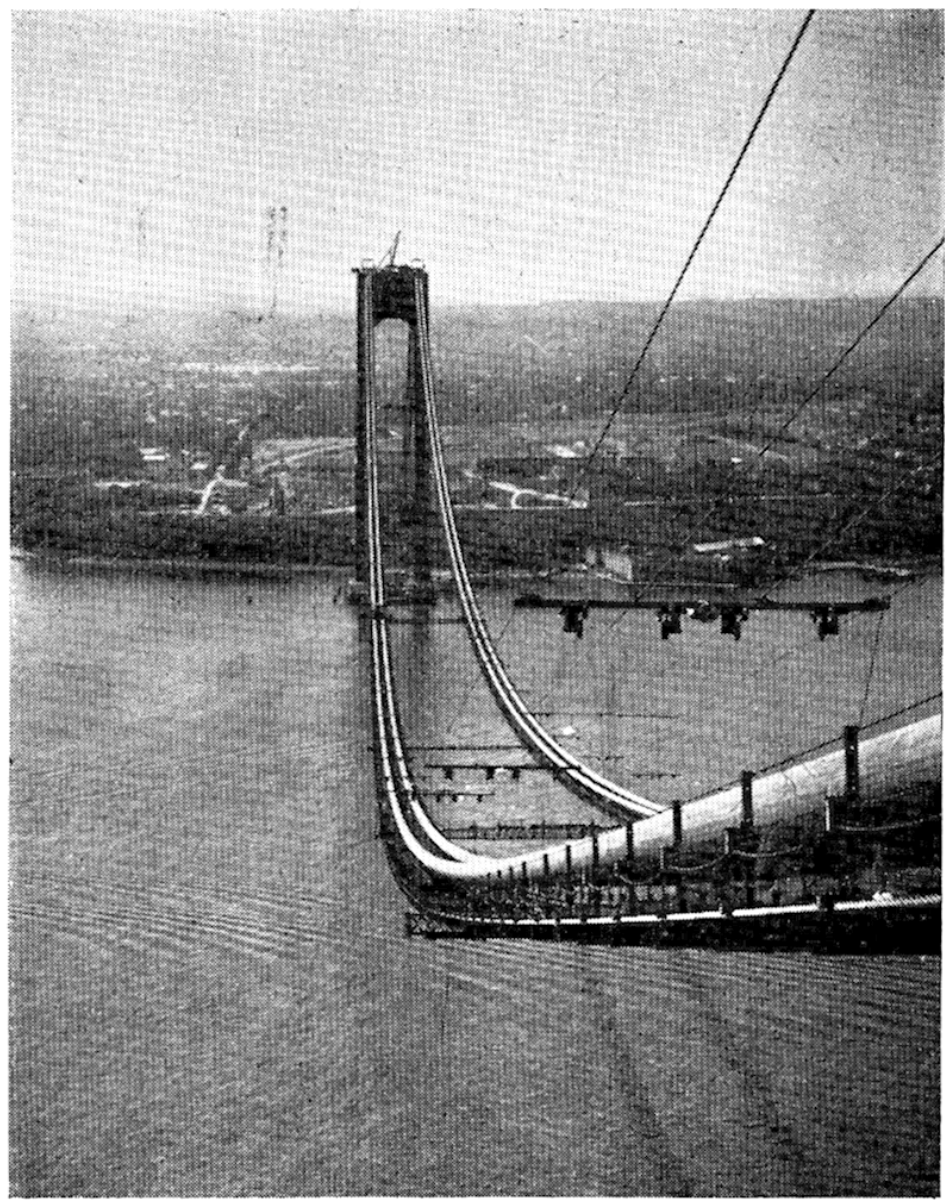

R. J. Mainstone (Copyright)

Fig. 20: Verrezano Narrows Bridge

starting point'. Mr Mainstone agreed, sharing as he did the Authors' interest in this architecture. Yet he felt that, in the Paper, too little emphasis had been placed on the last two words.

78. As engineers, we were interested chiefly in the relationship as it was today. Occasionally, as in the large suspension bridge, it was almost one of identity from the structural point of view: the structure was the form (Fig. 20). With qualifications, the same might be said of some wide-spanning roofs (Fig. 21). But in most structures there was now a much more complex relationship between the form and the structural organism. $^{1}$ Geometry still played a large part in determining the structural action. But hidden continuities, cellular construction, reinforcement, prestressing, and the use of steels and concretes of different strengths modified its influence in many ways (Fig. 22). 


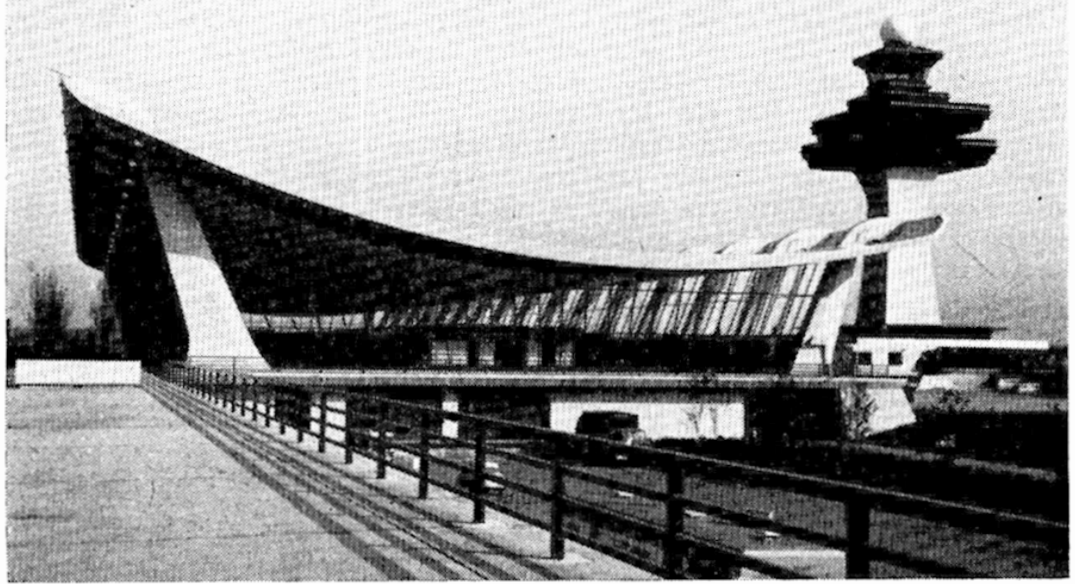

R. J. Mainstone (Copyright)

Fig. 21: Dulles International Airport, Terminal Building

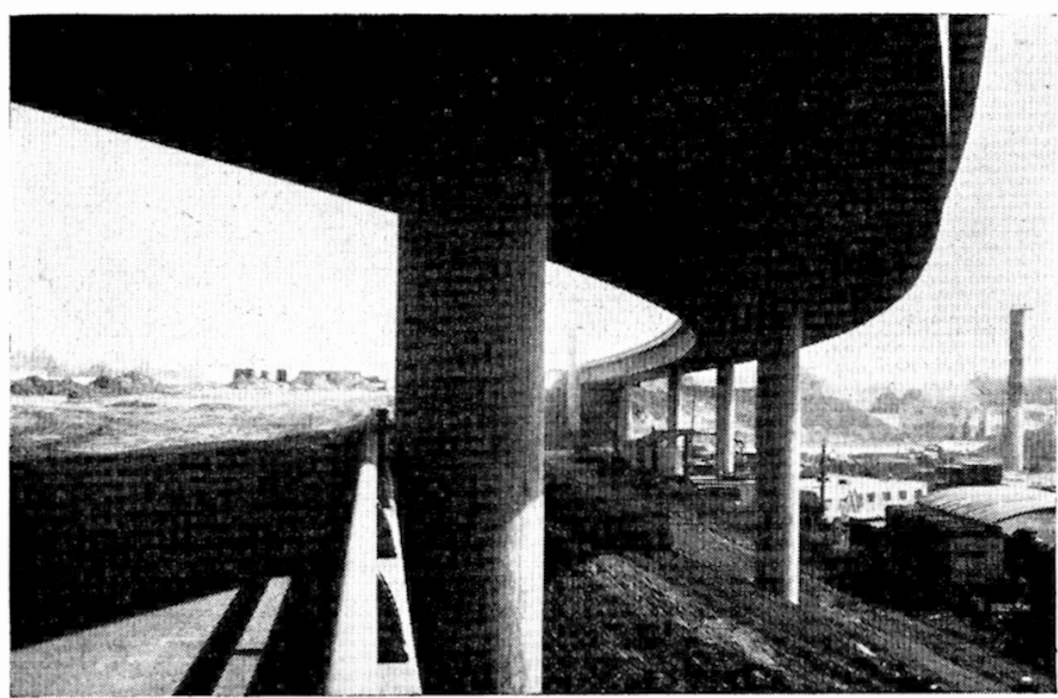

R. J. Mainstone (Copyright)

Fig. 22: Los ANGeles Freeway INTERChANGE 
79. By contrast, all buildings and bridges from the architectural past (if surface decoration, which was all that was seen in Fig. 5, was ignored), had a structure which, like that of the large suspension bridge, was simply, directly, and almost uniquely determined by the form (Figs 1, 2, 3, 23).

80. From the point of view of the structural aspect of the relationship, $\mathrm{Mr}$ Mainstone could, therefore, see only a limited relevance of past to present. We could start from the past, but we must seek and teach the relationship today very largely in terms of the present. A synthetic approach seemed necessary to complement the usual analytical one. But what form should it take? The Authors were strangely silent here, and this silence made their whole approach suspect-unnecessarily so it was hoped. Had the students' projects shown on the screen been conceived as structures or just as forms that could be made to stand? If more than lip service were to be paid to the basic tenets of the modern movement in architecture, the first was surely essential. Did the Authors agree? If so, how did they try to achieve it? Or, did they, while recognizing it as a desirable or necessary end, consider that the most that they, as teachers, could do was to inculcate a sense of form on its own, trusting that the best students would eventually arrive at their own synthetic concepts of structure as form?

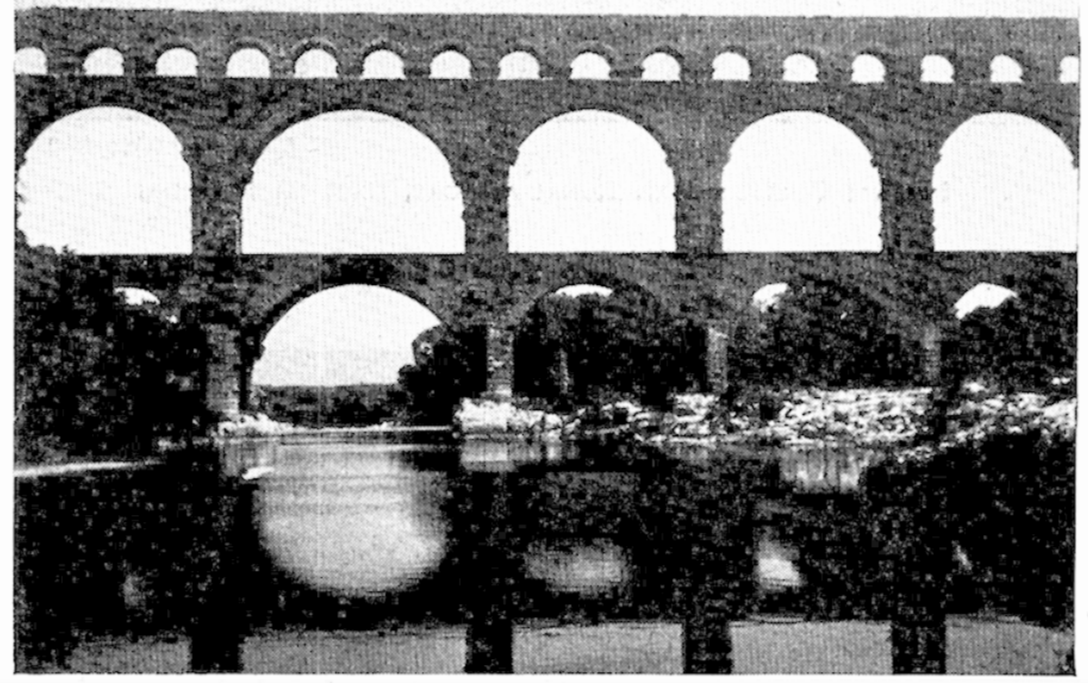

FIG. 23: PONT DU GARD

R. J. Mainstone (Copyright)

81. Far more attention had been given to the aesthetic aspect of the relationship, where all existing forms and our reactions to them were clearly relevant somehow. But could the architectural past be considered on a par here with the present? $\mathrm{Mr}$ Mainstone doubted this.

82. That doubt was partly a historical one. Not only did architects in the past face different problems and overcome them with different means: the 'uses of art' also were different in important respects. In particular, it was most unlikely that Pope's counsel in 'An Essay on Man',

'Know then thyself, presume not God to scan;

The proper study of mankind is man,'

would have been accepted by many of the designers of the buildings cited at the start 


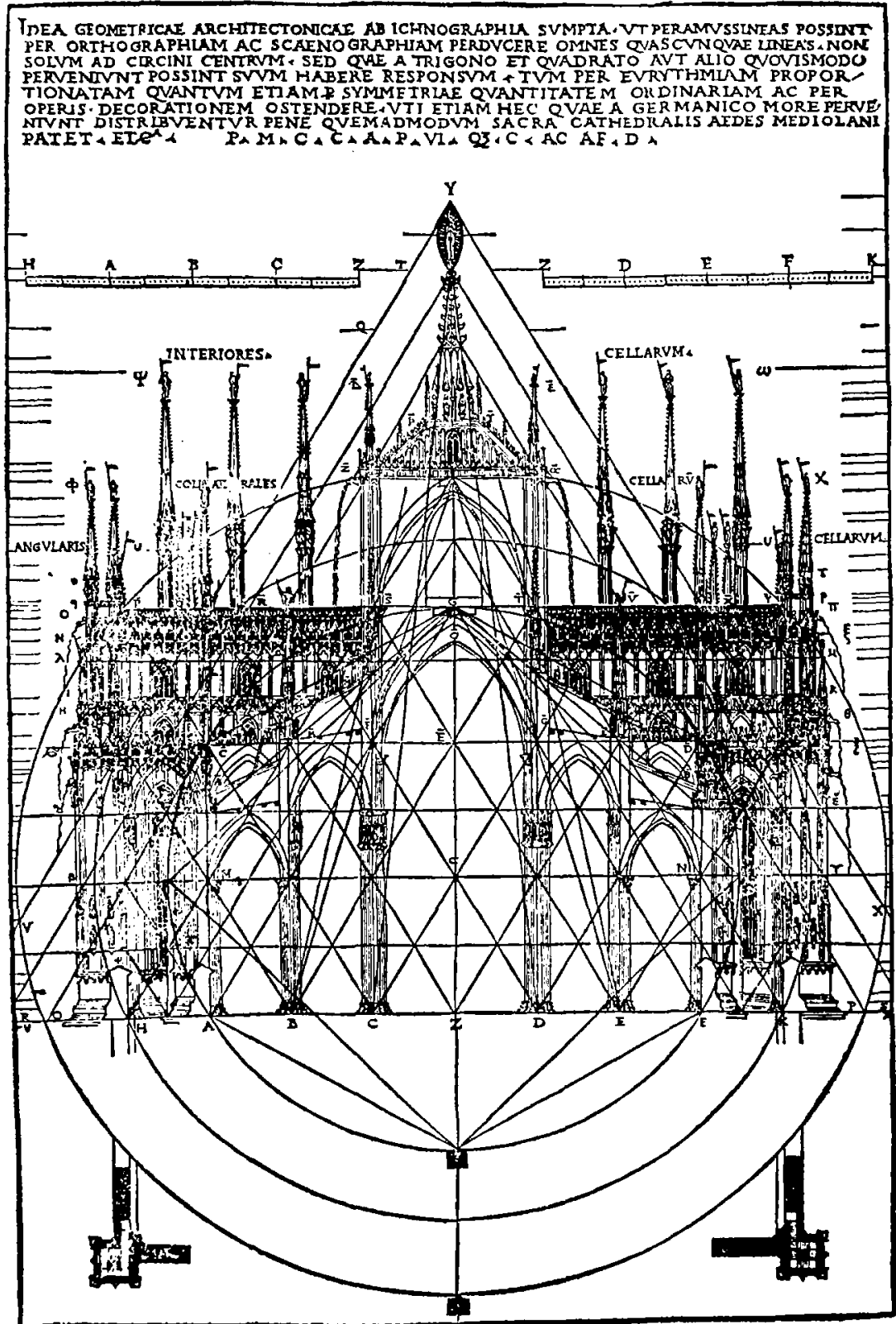

Courtesy: British Museum

Fig. 24: Milan Cathedral (from Cesariano's Vitruvius) 
of the Paper or by those for whom they worked. These men valued certain proportions, for instance, not because they were visually attractive in themselves, but because, both visually and as guarantors of structural integrity, they mirrored a supposed Cosmic order ${ }^{2}$ (Fig. 24). So the beauty that was now seen in such work was a quality stripped of many original overtones: a recent abstraction born of a change of attitude on our part and coloured by overtones of a different kind-age, historical associations, even pleasing decay (Fig. 1).

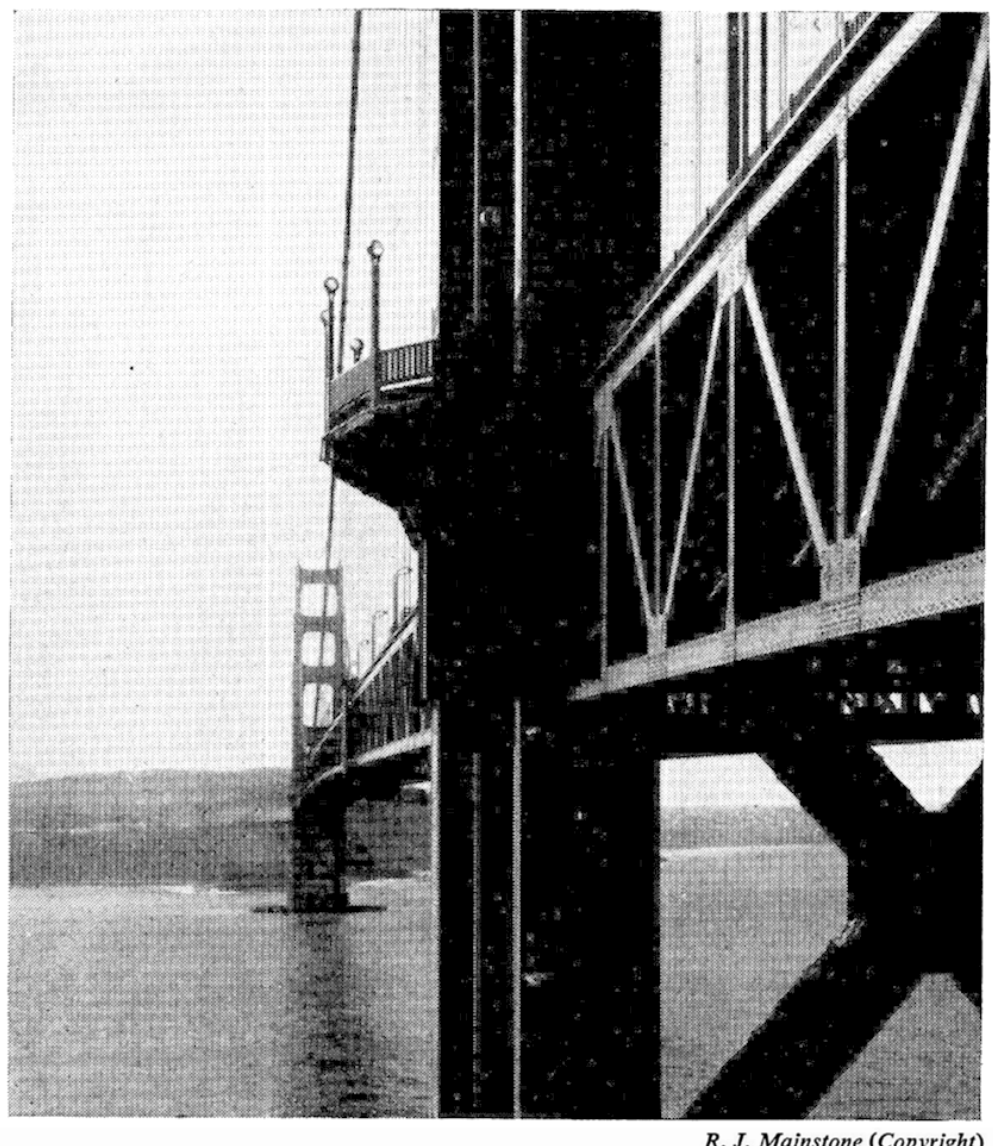

Fig. 25: Golden Gate Bridge

83. This beauty was, therefore, only partly relevant to a part of that quality which was sought today (Fig. 25). Must we each discover this relevant part for ourselves? Or could it be codified or otherwise distilled and mediated for the student?

84. As a student, Mr Mainstone had, in 1944, attended a series of lectures at the Institution on 'The aesthetic aspect of civil engineering design'. ${ }^{3}$ The first lecturer had then attempted a codification on the lines of $\S 30$ : the others had deliberately refrained. He could not help siding with the later speakers on two grounds. First, 
as Sir Patrick Abercrombie had said, 'the canon of beauty is not a fixed thing'. Secondly, the notions listed in $\$ 30$ were either too imprecise to serve as standards of judgment, or, if more precisely defined, far too restrictive. As usually interpreted, they smacked too much of the now unpopular Beaux Arts tradition.

85. His own belief ${ }^{4.5}$ was that the primary aims in teaching the creative side of structural design should be to instil that understanding of the structural potentialities of different forms already mentioned, to awaken whatever latent sensibilities there were to the visual potentialities, and to convey to the student, at the same time, the essential 'open-endedness' of the design process.

86. The best way of achieving the second aim must depend on each student's natural aptitudes. Painting, sketching, modelling or just looking at pictures in a gallery, could all play a part, as could a study of the architectural past. What seemed essential, if the last approach were adopted, was that the student should be led to feel the intensely moving quality, purely as space and form, of the interior S. Sophia, for instance, and the very different but still powerful impact of the Pantheon. This might not be easy. It called for considerable skill on the part of the teacher, and for at least some direct personal experience on the part of the student. Beyond this, it seemed to call for a close analysis of a few outstanding works rather than a quick look at many-for a study of the past that was intensive rather than extensive.

87. Such limited but intensive study could be invaluable also in introducing the student to all that was unchanging in the whole process of design. To see, for instance, the sort of problems that Brunelleschi faced when he set out to vault the crossing of the cathedral in Florence, the predetermined limits within which he had to work, the means at his disposal and the ways in which, as architect, engineer, and master builder, he decided upon the right courses of action and, as a person, he won acceptance of his ideas could hardly be bettered as an introductory insight into this. By contrast with the present, it could also lead to an understanding of what was new in the process today. ${ }^{6}$

88. This vicarious experience, looking over the shoulders of a few of the great designers of the past, might even be, for us, the main value of architectural history.

Mr R. H. Toms (Technical Officer, Paints Division, Imperial Chemical Industries) said that the subject for discussion was extremely interesting and provocative, but it was easy to become impractical in discussing it.

90. With regard to beauty and form, if one studied architecture of the past, as he enjoyed doing, for instance, in Norfolk and Suffolk, where there were many beautiful churches in the perpendicular style, one came away with a feeling difficult to explain, a feeling of excitement which arose from the form which had been created. A great deal of what could be learned about form and structure must arise from criticism of one's surroundings. There was a great deal of criticism today, and it must be healthy. Victorian architecture was widely criticized, but this must be all to the good. Even if the criticism was bad, it was better than the absence of criticism, since it meant that people were increasingly aware of their surroundings.

91. The subject must be of equal interest to architects and engineers, and it went further than architecture and civil engineering. The modern airliner was the result of structural and engineering requirements and produced a satisfying shape. In music, form and structure were synonymous and not separate. In spite of the modern tendency to specialization, with the fragmentation of civil and structural engineering and architecture, it was not possible to divorce form and structure, since one went with the other. If a building were given a structure, which meant basically a means of support, it must have some form, or shape.

92. He agreed with an earlier speaker that only in early buildings was there an automatic relationship between structure and form. This simple and direct relation- 
ship must have reached its peak in High Gothic, with its fan vaulting, flying buttresses, and so on. Examples of this were King's College Chapel at Cambridge and the cathedral at Wells in Somerset with its inverted arches, possibly a structural expedient but with an extremely pleasant result.

93. Latterly, with the mastery of new materials-steel and concrete, and possibly even timber-it had become possible more and more to set the form desired and adapt the structure to meet it. The Shell Centre and the Vickers building might be examples of the form required being the chief object. He was glad that Mr Harris had given examples of civil engineering and functional requirements dictating the resulting form almost entirely. Dams might be quoted as another example; whatever the dam site, a most satisfying structure seemed to result. Suspension and other bridge types were other examples, and possibly even power stations, with a large enclosure, a space basically dictated by the plant to go inside it, could be turned into a collection of forms which could be satisfying when seen from a distance. Going back to the past, post or tower windmills were the result of a direct solution resulting in extremely pleasant forms.

94. There was no longer the medieval attention paid to beauty in detail and as a whole, as shown by Chartres and its multitude of beautiful carvings. Today architectural effects were achieved often by contrasts of shape, surface contours, colour, and texture. The architect and the engineer were engaged in the successful, pleasing, and economic enclosure of space for a given use. There was every reason why they should be more and more closely involved together. The engineer must be highly concerned with the form and aesthetics of the structures that he helped to create.

Mr F. C. Greenfield (Senior Assistant, Hampstead Borough Council) observed that dogmatism in any sphere of art was always likely to lead to confusion. It was interesting to see how the Authors brought to light various creeds, none of which could claim universal validity. Indeed, the Greek Parthenon was only what it was because of its position on the Acropolis. He even wondered whether the Authors' final humanistic conclusion was wholly satisfactory. The late Professor Joad might have said: 'It all depends on what you mean by man.' Man, like woman, had a reputation for being fickle and subject to changes of mind and heart. Often he was not quite sure of what he wanted until he saw the result and then he realized that it was not what he wanted. Paris without its Eiffel Tower and its boulevards would be unthinkable today, but the controversy over Haussmann's demolition of the medieval city lasted for years, and there had been many objections by artists and philosophers to the dominating, but not beautiful, form of Eiffel's masterpiece.

96. Appreciation of any art required at least elementary knowledge of the subject, and in the visual arts, as in music, too much concern to please contemporary public taste led only to mediocrity or, at best, something far short of perfection. In the design of St Peter's in Rome the argument of Greek cross plan versus Latin cross lasted for generations. The final result with the elongated nave might be the most practical from the point of view of the user, but in destroying Michelangelo's main concept of the all-dominating dome, one wondered whether the sacrifice had really been worth while.

97. Nevertheless, a Beethoven arrogance or a Michelangelo 'terribilita' could only be forgiven in a genius, and lesser mortals would, on the whole, best serve their fellows by a patient determination to understand and sympathize with their needs and whims.

98. Accepting, then, that humanism must be and remain their outlook, it followed that satisfaction of the 'whole man' could not be achieved through structural forms which had nothing to say. Attempts to relate ideal architectural proportions to those of the human body were no more likely to succeed today than in the past. They should look to the functions rather than to the proportions of the body, thinking of their buildings as 'organic' with nerves, muscles, and bones clearly revealed and also 'kinetic', inviting the observer to move here and there, better to appreciate the changes 
of colour, texture, light and shade, so that the composition as a whole was interesting from any angle and distance. If, in the process, they exaggerated the strain in one member or reduced the apparent weight of another, what did it matter? Would St Paul's be the most perfect of all domes if it looked as weighty as in fact it was, instead of appearing to float upwards to high heaven? Today at last, man had the knowledge and the techniques to understand structure and should be able to bend it to his will as never before, unlike the man of the Renaissance, hamstrung with antiquity but never able to surpass it. Today they should take from the past just those lessons they needed to bear in mind, discarding the irrelevant and uninteresting, and proceed with their twentieth century knowledge to treat every case on its merits.

99. It was 200 years since the illiterate Brindley showed how to impel the observer under, over, and around his Hyde bridge (Fig. 8). Progress since then must be considered painfully slow, but the best work today possessed a vitality never known nor indeed possible in the past: a Maillart bridge (Fig. 19), compared in the Paper with a deer's leap, an Aero Saarinen airport building reminiscent of a bird in flight, a Le Corbusier church resembling the bows of a ship; all rendered possible by the possession of the most plastic building material of all time, reinforced concrete. What would Vitruvius have had to say about Le Corbusier's church at Ronchamp, so deceitful, but which in fitness for purpose and humanism had probably never been excelled?

100. The vast majority of architects and engineers today did not seem able to exploit fully their present-day knowledge or materials. That was probably because they were divided into two opposing camps, science and art. Even today many architects considered their art as something abstract and existing on a plane far removed from that of technology, familiarity with which they felt would cloud their imagination. On the other hand, too often the civil engineer preferred to remain intellectually aloof in his small slide-rule world, far removed from art. But where did architecture end and civil engineering begin? Ideally, a work of art should be conceived by a single mind. If the two professions had now drifted inexorably apart, might it yet be possible to join their members temporarily in the early stages of their careers? Could there be a common first year or part of the first year at the university, and in their last year, could they be taught to work together, the better to appreciate each other's idiosyncrasies? The foundation would thus be laid for common postgraduate courses in structural form and other subjects. In time, when the diehards of the old fight of art and science were dead, there might again emerge a race of men who understood structure with both mind and heart. In the meantime, those who might be too old to change could help the process along by inviting each other to their meetings, and the meeting that evening might prove a good beginning.

Mr Ove Arup (Partner, Ove Arup and Partners) congratulated the Authors on a very useful Paper and commended the fact that it did not come down in favour of any particular architectural theory but picked from each the grain of truth which it contained. He liked also the recognition that art was useful and all-pervading and that artistic criteria should apply to all man-made objects which formed part of the human environment. Although the Paper touched on most of the views expressed by architectural philosophers or critics, in the end its readers were left no wiser about what good architecture was. This was probably a good thing, because it was better to acquire the wisdom of Socrates, who at least knew that he knew nothing, than to cling to fixed principles or dogma which could be successfully defied by any gifted designer with an original cast of mind.

102. The modes of artistic expression were as varied as life itself. But this was not the same as saying that there was no difference between good and bad in art or architecture, that it was all a matter of personal taste, and that each person's taste 
was as good as anyone else's. There was such a thing as good or bad taste. Naturally each person had a right to follow his own taste, and should do this, but he also had a duty to develop that taste, at least if one subscribed to the maxim that man should try to develop his potential. For taste was not something stationary, it did develop, and could be deliberately developed if one applied oneself to it.

103. To become a good judge of horses, of wine, of music, poetry or architecture, in fact of anything with an artistic content, required in each case both an innate aptitude and practical experience in exercising that aptitude. It was no good trying to reduce such judgements to the application of a set of rules but most people would agree that there was a difference between the judgement of a connoisseur and a complete ignoramus in the particular field.

104. Structural engineering and civil engineering certainly contained an artistic element because they involved the design of structures or 'features' which would form part of our environment. If engineers wanted to be considered fit to be in charge of the design of such features, it was necessary that they should also apply themselves to the artistic side of their task. That was why the initiative taken at Leeds was so important for the future education of engineers. It would be wrong to expect too much, however. Even architectural students who probably got ten times as much opportunity to exercise their talent for design, and who for five years were steeped in an atmosphere of aesthetic awareness, did not always end up as sensitive designers-far from it. And presumably they started off with - on an average-a larger artistic potential, since they chose this particular profession.

105. What one could hope for was to train engineers who were at least aware of the importance of aesthetic considerations, and who had some understanding of what architects were trying to do. Without such understanding, collaboration between these two professions would suffer. And one might further hope that some engineers who had a natural gift for artistic creation would benefit to the extent that they would become in fact architects as well as engineers, in the sense that their engineering designs would be works of art as well as making structural sense.

106. Engineers had a contribution to make to architecture. The result of their work was in fact architecture and would be judged as 'such. Architects should - in the interest of architecture - welcome and make use of this contribution-because if a building or 'feature' was structurally unsound or confused, this would detract from the architectural quality as well. When architects ventured outside their proper field and embarked on the design of 'features'-bridges, large halls, shell structures etc. - whore the structural element was fundamental to the design, then the result could be deplorable. In such cases it was quite wrong to call in the engineer to make an architectural design work; it would be better to let the engineer be the originator of the design, with the architect as adviser. But the engineer then had the duty to see that the very important architectural aspect was not neglected.

Mr N. V. A. Crick (Architect, Ministry of Public Building and Works) said he was a little disturbed by the direction which the instruction at Leeds seemed to be taking. He was gratified to know that engineers were being taught to look at problems from an overall point of view first, but he was not sure that it was a good idea to introduce the design of houses and other purely architectural subjects to engineers on a 3-year course. It was a truism that a little knowledge was a dangerous thing, and he felt that this particular piece of knowledge might be very dangerous indeed.

108. He felt that engineers should be instructed in "engineering aesthetics', and the great examples from the past should be studied. Designers of 'prestige buildings' throughout the ages had been mentioned. Both Brunel and Nervi would consider themselves first and foremost to be engineers, but they were successful architects because their thought processes were right and because they allowed their knowledge of structure to dictate the aesthetics of the building. Mr Crick thought that it was this approach which should be taught to engineers. 
109. He would add that architectural training should include very much more engineering and a greater appreciation of engineering possibilities and potential. He did not think that architects needed to concentrate too much on the niceties of engineering design, but they should have a greater understanding of what the engineer could achieve.

110. There was a long way to go to overcome the problems of co-operation and co-ordination in building. He had always tried to obtain engineering consultation at the earliest possible moment in the conception of a new building, but this had not always been successful; there had been early consultation, but less had come out of it than he had hoped. The engineer's attitude had been 'You draw it and we will design it', but that was not what was wanted. Very often he wanted to find some original structural form which would dictate the architecture and ensure that the entire building was a unified and consistent whole. Every aspect of the design of the building, the detailing, right down to the architraves, if there were any, should all be influenced by the basic structural decision.

111. While agreeing with most of what $\mathrm{Mr}$ Arup had said, he felt that there was still a tendency in engineering circles to think that there were some buildings which were engineering problems and which engineers would design and then at the last moment call in an architect to complete and get through the planning authority. That attitude did prevail. He had heard recently of a director in the Ministry of Public Building and Works who assessed the architectural content of a building at $15 \%$ and bid for staff on that basis. Anything that appeared above the ground and could be seen in the form of a building should be a piece of architecture and should be 'architected' from the start. The first line that was drawn must come from the architect's pencil, even though it might be that consequently most of the work would be done by engineers, but the architect should initiate the scheme. He knew of no exceptions to that.

Mr D. E. Glover (Assistant Engineer, Port of London Authority) said that engineers sometimes met the architect who wanted to draw the outline and pass the design over to the engineer yet retain for himself an exclusive title as the designer of the building. On the other hand, such cases arose, as for example Waterloo Bridge, where the architect had been invited in the last minute to 'architect' the engineer's design, yet it was the architect who had gone down in history as the designer. There were many cases of that kind, which frustrated the engineer's claim to conceive and execute complete projects.

113. The importance of an ability to draw should be emphasized to all engineering students. This was where aesthetic appreciation started with engineers and architects alike. There were architects who were not very good at it and there were engineers who were very bad at it. Some engineers were better at it than some architects; of that he was convinced. Engineers should not try to follow in the footsteps of architects, but there must be mutual understanding between the two professions. This country needed wonderful buildings but it was not getting them. Would any architect be prepared to name a dozen really first class buildings built since 1945? There was a problem in architecture as well as in engineering.

114. Improvement could be made if students were led to produce a good drawing and have a basic understanding of art.

Mr B. G. Combridge (Chief Engineer's Department, London County Council) said that, without disrespect to the previous speakers, he had hoped that the designers of structures accepted to be of fine form, such as Coventry Cathedral, the Post Office tower, or Hammersmith Flyover, would have come forward to communicate the 'thought processes' behind their designs. Perhaps they might be prevailed upon to contribute to the written discussion. 
Mr Allan Johnson, (Partner, Lanchester \& Lodge) said that he did not want to enter into a discussion as an architect against engineers. In some respects it was a pity that architects and engineers were trained in such completely different ways. It might lead to the possibility of misunderstanding and to difficulty in working together, but he thought that the difficulty existed only at the beginning and disappeared as soon as they began working together.

117. He had found that in working with engineers, they criticizing his ideas and he in turn criticizing theirs, by the time they had finished the work the engineer was a better architect that he had been originally and Mr Johnson was further on the way towards being an engineer.

118. Although he often went to Leeds and had worked very satisfactorily with Professor Evans as a client, he had not seen a great deal of what he had been trying to do, but like previous speakers he felt that it was an excellent idea to teach an appreciation of form and shape particularly in three dimensions. Too often we were all guilty of looking at two dimensions on paper and forgetting the third. It might be that some form of modelling, for example, in clay, would help. He had greatly enjoyed the Paper and wished the Authors more power to their elbows.

\section{The following contributions were received in writing:}

Mr P. C. Edwards (Design Engineer, Harris and Sutherland), referring to Professor Evans' closing remark on Mr Candela's design approach to a structure, wrote that the uninspiring appearance of many contemporary developments in this country might well be due to the following unfortunate but common situation.

120. The designer, be he architect or engineer, designed and planned a structure, a complex of structures, or a complete development of any kind (sewage works, town centre, new university, etc.) as an artistically balanced unit, related soundly to its environment, function, and its future inhabitants or workers. However, in the detail design and construction phase, the project passed out of the original designer's immediate supervision, and the more complex it was, the more people would, for reasons of their own, alter their part of the overall plan until the original concept was entirely destroyed.

121. This problem was very acute at all levels in the construction industry today as many specialists were involved; one could not really imagine any other industry producing a product in the way that engineers tried to do. Once the original design had been 'sold', every designer with an overall responsibility for any type of development should appoint one of his staff (responsible to him personally) to make sure that the original conception was not destroyed in the conflict of interests that would inevitably arise.

122. The need for this type of 'liaison' engineer might possibly diminish in future if all concerned with construction had more of their initial training in common and were taught, from the start of their careers, to think about the impact on others of their own design processes, and about the true nature of design itself, as the Authors were trying to do at Leeds.

123. Their inspiring lead should be followed without delay by a closer liaison between the universities and practising engineers and architects, who must be persuaded to assist the universities in many ways besides merely financing research. By giving lectures and by joining actively in student projects, design offices and contracting organizations in all construction fields would be able to help teaching staff to fire the students' imagination and enthusiasm and in return would be able to take into their organizations graduates who would bring with them new ideas: graduates taught not to imitate but to initiate, taught to think and not just to remember. One would not then ever need to hear again the sad reaction of many engineers (and no doubt architects) to a new 'intake' of graduates: 'What on earth shall we 
give them to do for six months.' And then perhaps our cities and countryside would be disfigured by somewhat fewer eyesores.

Mr E. A. Turner (Senior Engineer, Ministry of Public Building and Works) wrote that the excellent Paper, and the Authors' introduction, gave rise to a discussion which revealed the concern felt about the present day tendencies to higher specialization in education.

125. The Paper was concerned in particular with engineers and architects. Those were of the same breed of men. Some were able mathematicians and poor artists; others were good artists but poor mathematicians; but there were all gradations between, with divers other attributes, and the differences between them were more the result of their training than of their capabilities. The encouragement of artistic capabilities in engineering students at Leeds revealed that they had a considerable reservoir of these abilities. The converse no doubt existed in architectural students.

126. The tendency to higher specialization in education was one that had grown over the last decades. In the last century, the engineer and architect were on much more common ground and, in fact, were often one and the same person. The tendency existed, not only in science and all branches of engineering, but in other spheres also. It was the result of an examination system of qualifications which had required a higher and higher level of knowledge in the subjects of examination. This had necessitated a concentration on these subjects at the expense of more general knowledge, so that universities were becoming no longer places where students could learn to understand each other better, but colleges for the acquisition of specialist crafts. This was the fault not only of the universities but of the professional institutions which framed the examinations. It was a fault not found in so extreme a form in other countries.

127. The situation was the more regrettable in that, despite the high degree of specialized knowledge that a graduate might acquire, he would need, in order to advance (unless he could become outstanding in his particular craft) to acquire knowledge of other crafts in order that he might co-ordinate them with his own. There was, of course, a need for specialists but they were best trained in postgraduate courses or in industry.

128. It was the tendency for engineers to become highly specialized that had left the field of higher administration open to the layman.

129. Was it not necessary to broaden the scope of engineering education even to include the arts? The student must be afforded the opportunity of graduating at a lower pass level over a wider range of subjects.

Mr Herbert Addison (Consultant) was interested in the very illuminating sentence in $\S 52$ of the Paper: 'It becomes, then, the first duty of the artist-engineer no less than poet-fully to learn the needs of those who are to use his product and fully to explore their capacity for understanding and response'. How was that exploration to be carried out? What was the equivalent of the art critic when the work under review was not a poem, piece of sculpture, or a painting but a bridge or a powerhouse?

131. Such informed and perceptive criticism was not to be found in the 'Arts' pages of daily newspapers and was rarely seen in the descriptive pages. When the Ffestiniog pumped-storage scheme was inaugurated recently, what newspapers had anything to say about the architectural merits of the main building on which so much thought had been bestowed? It was true that recently a Sunday paper published quite an attractive drawing of the Hammersmith Flyover, but instead of commenting on the distinctive and indeed unique shape of the structure, it merely described the flyover as 'typical'. Broadcast programmes such as the B.B.C. 'Critics' and the B.B.C. TV 'Monitor' items were equally unresponsive.

132. Would the Authors of the Paper agree that it was hardly possible to trace 
the significant relationship between form and structure in modern engineering works without knowing the local conditions that controlled their erection? Within the space of 10 years, structures had risen before our eyes as fundamentally different as the bridges over the M1 motorway, those over the Doncaster A1 motorway, and the partly-finished overhead M4 motorway. The exceptionally heavy appearance of the earliest of these had been explained by the need for rapid construction; the lightness and elegance of the Doncaster bridges was the reward for refinements in prestressed concrete technique; while the special construction programme imposed by the site had doubtless given an air of insensitivity to the T-shaped columns of the M4 viaduct.

133. Without some such understanding, how could engineering or architectural students be guided towards a critical assessment of great works of construction, especially when their own university halls of residence might be decorated by abstract compositions inspired by feelings completely alien to their own professional ones?

134. As for the users of the engineer's products to which the Authors referrednamely, in the present instance, the drivers of motor-cars-they sometimes had the capacity for quite vigorous and even rewarding responses. If they had visited the Royal Academy summer exhibition a number of years ago, they might have noticed in the architectural section an artist's drawing of the proposed Wentbridge viaduct on the A1 road north of Doncaster. Much later, they might have made a special effort to study the finished structure itself - helped by a thoughtfully-sited lay-by-and on walking down into the quiet valley beneath they could assess the boldness of the conception. Its powerful dramatic impact called to mind a setting for "The Magic Flute' or 'Die Freischutz'.

135. Such experiences underline a difficulty that had been mentioned at various recent meetings of the Institution: that whereas it was usually easy to look at a drawing or a photograph of a bridge or viaduct, the visitor who wanted to examine the structure itself would virtually have to organize an expedition in order to do so.

Mr D. W. Smith (Associate, Mott, Hay \& Anderson) wrote that the Authors were to be heartily congratulated on producing a Paper of outstanding value and importance. Their careful elucidation of the relationship between structure and form would help to steer engineers between the extremes of over-simplifying it on the one hand, and altogether ignoring it on the other. Particularly useful also was the emphasis on education as the road to a better understanding.

137. The malaise into which engineers had fallen, resulting in their frequent failure to produce structures of beauty, might be diagnosed as 'exploiting the discipline of structural analysis' or some other allied discipline ( $\$ 37)$. As soon as a discipline could be exploited, it ceased to be a discipline. In the hands of a genius like Nervi, or Wren, or the architect of the monastery library at Melk, such exploitation might produce sound structures of delightful form. But common mortals, unless bounded by a suitable discipline, soon lost touch with the demands either of structure or of beauty. So there were engineers who cared nothing for visual beauty, and architects who cared for nothing else.

138. It was necessary to enquire what the ordinary run-of-the-mill engineer could be expected to do, and educated to do. He could not be expected, except on rare occasions, to produce structures of outstanding beauty; indeed it was doubtful whether a city composed entirely of such structures would be a satisfying place in which to live. A few structures ought to demand attention and satisfy the lingering eye; others should not call attention to themselves, either by great beauty or by great ugliness.

139. Similar remarks applied to engineering works in the country. Unless the landscape was unusually dull, it was a complete mistake to speak of enhancing it with a motorway. What we could do was to avoid marring it unduly. Creation was good. Man was either for it or against it-he could rarely improve upon it.

140. A genius was born, not made. Education could produce a good run-of-the- 
mill engineer, who might by all means learn to delight in beauty, but who should be trained to produce what was not positively ugly.

141. It was significant that the only ugly illustration in the Paper (Fig. 10) was also the only one of a whole district, rather than a single structure. Unity in one structure was produced by one designer $(\$ 28)$. We had scarcely yet begun to solve the problem of how to produce satisfying unity in a district occupied by a number of owners and different types of user. Were all these individuals to be free? If not, who was to control them? How would such control be exercised without stultifying them? Could a democracy be relied on to choose, and maintain for a sufficient length of time, a man with the necessary force and ability to exercise control to good effect?

142. It was to be hoped that $\$ 61$ was to be read for what it said, and not for what, at a quick glance, it seemed to imply. An engineering drawing too was a work of art, to be judged not by its frills, but by its fitness for use-clarity, economy, order. Drawing office work was creative, and ought never to be drudgery. Drawings, like all other products of art, were a means of communication. They were the language in which engineers talked to each other and to craftsmen, and they were a powerful aid to clear thinking. Mastery of this language was as necessary to a designer as understanding of his materials.

Dr G. C. Brock (Head of Department of Civil Engineering, Loughborough College of Technology) wrote that the most important part of this interesting Paper was contained in the final section, devoted to education. The actual treatment of form and structure should be discussed thoroughly in our engineering schools. It was, of course, notoriously difficult to do this by the systematic methods which were used for teaching engineering science. To omit, even on the grounds of difficulty, the serious consideration of the purpose and philosophy of engineering was to promote a fundamental weakness in engineering education.

144. Civil engineering was far from the being study of a single discipline or even a group of related disciplines. The growing variety of arts and sciences relevant to its practice meant that no one man could now hope to master the whole field. But there was still a tendency in some schools to attempt to produce a standard engineer and to try to make him essentially a scientist. The Authors had done the profession a service in emphasizing the need for more training in creative skills and for drawing attention to the practice in schools of architecture.

145. There had been very little co-operation between schools of engineering and of architecture in the past. However, contacts were being made in several centres and Dr Brock had learned their value by personal experience. Too many civil engineers remained unaware of the changes which were taking place in architectural education and still looked upon the architect as an 'artist' of the Beaux Arts school. The modern schools of architecture were seeking to provide education in which creative skills and the application of science and technology went hand in hand.

146. To achieve a balanced education, the civil engineering student needed to spend more time learning creative design skills. Over 30 years ago, Hardy Cross wrote of "the danger of finishing the study of indeterminate structures without understanding the application of analysis to design - all dressed up intellectually but not knowing where to go'. ${ }^{7}$ Since then the pressure of analysis had increased and it had become even more unusual to find time for design work within the curriculum.

147. Although the work of Cross failed to make time for design the even more powerful tool of automatic computation might do so. Already, merely by filling out a data input form, a person without much detailed knowledge of structural analysis could obtain the answer to problems which formerly would have occupied an expert for some days. It was becoming possible to devote some of the energy formerly expended upon analysis to choosing the problems for analysis and evaluating the results in terms of the real structure. 
148. The change in educational emphasis suggested by the Authors was similar to that put forward by Francis. ${ }^{8}$ If engineering was to be a creative force, we must not neglect the lessons to be learned from the teaching of other practical creative pursuits such as music or architecture. In such subjects progress was made by practice and criticism. The systematic organization of knowledge which was taught by the scientist could result in sterility of outlook in the engineer if pursued too far or too quickly. There was little reason why a student must learn all his science before making acquaintance with his art. There was even less reason for him to make no acquaintance with his art at all.

Mr A. F. Fulwood (Senior Lecturer in Civil Engineering, Hatfield College of Technology) wrote that in the section on education the Authors had made suggestions that could lead to a reappraisal of undergraduate courses in civil engineering. With the ever-widening fields of analysis there was some danger that our educational system was tending to produce analysers and not designers. In interviewing new students, one looked for a creative interest as well as a basic ability in mathematics and mechanics. But the only 'design' these students did during their course often consisted of selecting the appropriate size of reinforced concrete or other section to support a given loading. Admittedly it was easier to examine work of this type, but would it not be preferable to teach design in which students would be expected to consider every aspect of the problem and not only the stress analysis? From time to time one heard complaints by employers that their graduate engineers were able to undertake much of the complex analytical work but were completely unable to produce even a simple design. If the design process was essentially scientific, it should be possible to teach it, and such a study would involve the development of skills suggested by the Authors.

150. They pointed out that this took time, but would not a closer integration of course work, or project work, in individual subjects result in better use of the time available as well as leading to the development of an overall concept? Some architectural schools did much of their teaching by project work, usually of a nonmathematical nature, which was intended to develop the understanding and skills required of the designer of any structure.

151. Might it therefore be suggested that an approach be made by the Institution to the R.I.B.A. with a view to forming a small study group from both Institutions to discuss the place of design in the education of engineers and architects. Such a group might do much to narrow the differences in education and often, regrettably, in the outlook of members of the two professions.

Mr D. J. Lowes (Senior Engineer, Ove Arup \& Partners) wrote that in his reply to oral discussion, Professor Evans mentioned that many eminent architects, including past-presidents of the R.I.B.A., had told him that, given their time again, they would choose to study structural engineering before beginning their formal study of architecture. This would, therefore, seem to be an opportunity to ascertain what an engineering graduate might rightly expect by way of academic credit if he wished to enrol as a student of architecture.

153. Certainly such architects as the Authors had spoke about would welcome engineering graduates as architectural students. It might be expected that the qualifications and experience of such students would, to some extent, be taken into account in deciding the courses which they should attend and the examinations that they must necessarily pass. Apart from the probability of the engineering graduate also having to earn his living, like anybody else he would wish to devote the maximum amount of his energy to those subjects which he had not studied before. The graduate engineer might also prove rather a challenge to his architectural teachers since they would need to appreciate not only the student's understanding of an important part of the syllabus, but also the fact that he had already acquired something of the 
technique necessary for fruitful study. The suggestions of the Board of Architectural Education would appear to justify optimism about official regard for previous experience.

154. There was, however, at least one school of architecture where these perhaps enlightened principles did not seem to be wholly acceptable. A student who had undergone engineering training might be forgiven for believing that, far from being encouraged, he was viewed as something of an upstart. It was therefore to be hoped that the profession of architecture would exercise its influence where it could on any school which aimed at less than the educational ideals expressed by the leaders of the profession.

Dr J. T. Manning (Engineer, Harris and Sutherland) wrote that it was surprising that, in a Paper on form and structure in engineering, the Authors omitted the architectural development and engineering problems associated with the development of the arch from the mediaeval or Norman period to the early English or Gothic period.

156. When the circular arch was superseded by a pointed arch to obtain a more elevated ecclesiastical appearance and massive cathedrals were constructed of stone, the thrust at the springing of the arch created a problem for the thirteenth century builders. This was overcome by constructing flying buttresses from the arch springing, the thrusts being carried to the main buttresses which depended on their mass for stability. The structural honesty of this form of construction was apparent, as no attempts were made to conceal or ornament the buttresses; even the pinnacles were functional, adding to the vertical load.

157. A good example of this might be seen at Westminster Abbey (1245-1270) where a double system of flying buttresses was employed. The boldness of these structural requirements had created an architectural feature.

158. Buttresses were often similarly used in present day building as architectural features in preference to tie beams or a heavy edge beam or column. The Commonwealth Institute Building, London, and Liverpool Cathedral were good examples of the use of buttresses to enhance shape and simplify construction.

Professor R. H. Evans (joint-Author), in reply, expressed his gratitude to all those who had taken part in the discussion. In reply to both Mr Harris and $\mathrm{Mr}$ Toms, he said that at the University of Leeds there were large numbers of civil engineering students; the entry of new students per year was about 100 . It was possible to produce large numbers of graduates with quite adequate skill in methods of analysis, but that, today, was not sufficient, and the time had surely come to think afresh about the training and education of civil engineering students. The same applied to engineering students pursuing courses in the allied professions.

160. The real problem at universities such as Leeds, as in every other place of higher education, was that students entered the University after specializing intensively in the sixth forms in Pure Mathematics, Applied Mathematics, Physics and Chemistry. It was no exaggeration to say that no other country in the world specialised so much as Gt Britain in pure science in grammar schools, and it had to be realized that the major part of pure science in the sixth form was analytical. It was therefore natural to expect students entering the universities to have acquired an outlook that had been determined by methods of analysis without any reference whatsoever to the reverse process, namely, synthesis. Until the students came to the university the problems had really been directed towards calculating various factors, deriving and proving certain well-known expressions with little attention paid to design or practical application.

161. The first problem facing the university schools of education was therefore to break down the barrier between analysis and synthesis, since the main function of education was to encourage young men and women to spend as much time as possible 
learning for themselves and to send them down anxious to introduce new ideas. If this object were not achieved, Professor Evans felt that education in the engineering schools had somewhat failed.

162. Bearing this in mind in his reply to $\mathrm{Mr}$ Mainstone, Professor Evans stated that it was essential at some early stage to encourage students to use their initiative and to give of themselves. After a time students should then be given specific but not too difficult projects in order to discourage them from merely copying similar schemes from textbooks. For this purpose freehand sketching should be cultivated and encouraged and this aptitude should be nourished in the first year at universities.

163. He agreed with Mr Ove Arup that possibly the most rewarding and quickest response would be obtained if students went to an engineer's office where really first-class work was being done. On the other hand, many former students came to see him after having served one, two, and more years in the offices of engineers and complained bitterly about the enormous amount of routine work that was going on. Much of this work did not demand any intellectual thought from the young men and they became, on the whole, dissatisfied. This was a great pity, and the engineers in charge were largely to blame. It was essential that all those in charge of drawing offices should take much greater interest in graduate members, since drawing offices should be really places of inspiration. In some offices this was quite true and the graduate trainees were full of fire and most proud to tell him what they were doing. Unfortunately this was not the general case and there was much room for improvement.

164. This again raised the question of whether new types of courses were necessary, and when he discussed this with a number of distinguished architects, he agreed with $\mathrm{Mr}$ Arup that the time had come for a much closer liaison between structural engineers and architects, and possibly for the introduction in universities of combined courses including structural engineering and architecture. It was possible for the present schools of engineering and architecture to devise a four- or five-year course combining structural engineering and architecture and it would ultimately lead to degrees in architectural engineering. There was no doubt that such courses would offer far better opportunities to students to develop their innate creativity in the fields of structural engineering and architecture.

165. He was more or less in complete agreement with much of what had been said by $\mathrm{Mr}$ Ove Arup.

Mr W. Houghton-Evans (joint-Author) added that he too had been heartened by Mr Arup's contribution. Architects had much to learn from engineers, but his object at Leeds was not to train engineers to do work which, for good or ill, was primarily the concern of another profession. His purpose was to improve their handling of those things which were quite properly the engineer's prime concern, and which contributed in large measure to town and landscape. While he disliked some of the illustrations shown in discussion he thought the main fault lay not so much in the design of the individual objects, as in the bad town planning which their siting showed. It was the prevalence of bad design in that sense which was the real measure of the problem we face today.

167. The Authors emphasized (especially to those contributors justly regarded as experts) that their Paper was aimed at the generality of the membership, although they trusted that they had neither 'talked down' nor made concessions on matters of principle. Their purpose had been to clear away prevailing misconceptions and to prepare the ground for what they hoped would be a continuing discussion. Perhaps a suitable occasion would later arise when the more profound aspects could be debated more adequately. They would not, therefore, attempt to answer in detail 
many of the valuable points raised. Much which had been advanced in apparent disagreement, they thought would be met by a careful re-reading of the Paper. Since, however, one or two contributors appeared to have misconstrued them completely, they thought it would help briefly to reiterate their main argument:

1. Satisfactory form did not necessarily or inevitably follow from 'correctness' in structural design, the use of materials, proportion or composition, although all these could contribute towards it.

2. The form would satisfy visually to the extent that appearance contributed to the total satisfaction experienced in the use of the designed object.

3. The creation of 'beauty' was thus intimately bound up with the many-sided problem of utility.

4. The solving of this problem required wide knowledge, sympathetic understanding, and a skill in the selection, analysis, and organization of diverse data in a complex design process.

5. That skill was, in the main, to be learnt only through practice which, in greater measure than was customary, should be integrated into the undergraduate's education.

168. They had concluded that some educational reform was therefore necessary, and it was gratifying to find that this topic had become the main theme in discussion. $\mathrm{Mr}_{\mathrm{C}}$ Crick was right to have warned against encouraging precocity in complex architectural matters. Mr Smith was right to have stressed that teaching must be addressed in large measure to the 'run-of-the-mill' engineer rather than to the exceptional genius. They would nonetheless agree with $\mathrm{Mr}$ Arup that the result of much of the engineer's work was, in fact, architecture and should be judged as such. The parallel educational practices in schools of architecture were, therefore, (as Dr Brock said) worthy of study. Messrs Harris, Brock, and Fulwood confirmed the Authors' view that design skill was to be learnt practically. They agreed with Mr Mainstone that the problems involved in design defied precise codification and that an understanding of them could not be learnt from formulae. Mr Greenfield's suggestion of a partly common course for architects and engineers was a possibility increasingly discussed, and they hoped it would be tried. The other suggestions for improving the architectengineer relationship they, of course, equally supported. Cross-fertilization by the various methods suggested should, at the least, promote the sympathetic collaboration in later life advocated by Mr Edwards. At the best, it should produce engineers and architects both better able to exercise leadership in their respective fields. For their own part, the Authors were developing their efforts to educate engineers in both the theory and the practice of creative design. Their own understanding of how to overcome the many attendant difficulties was growing accordingly, and they hoped before long to be able to supplement what they had already said with further evidence of success.

\section{REFERENCES}

1. R. J. Mainstone. On construction and form. Program (Journal of the Columbia University School of Architecture, U.S.A.), Spring 1964.

2. R. J. Mainstone. Structural theory and design: 1. Early proportional theories. Architecture and Building, March 1959, pp. 106-113.

3. The aesthetic aspect of civil engineering design. Institution of Civil Engineers, London, 1945.

4. R. J. Mainstone. Discussion on 'The architect and the engineer'. Proc. Instn civ. Engrs, vol. 13, August 1959, pp. 525-527.

5. R. J. Mainstone. Aesthetics in structural engineering. Engineer, Lond., vol. 193, 25 May, 1962, pp. 921-923. 
6. R. J. MaInSTONe. The springs of structural invention. J. roy. Inst. Brit. Archit., vol. 70, February 1963, pp. 57-71. Also discussion by W. Houghton-Evans and R. J. Mainstone, vol. 70, April 1963, p. 163, and May 1963, pp. 207-208.

7. H. Cross and N. D. MorgaN. 'Continuous frames of reinforced concrete'. Wiley, New York, 1932.

8. A. J. FrancIS. Engineering education and engineering practice. Engineer, Lond., vol. 211, 26 May, 1961, pp. 848-852. 